\title{
Differential Aspects of Sleep Epilepsy
}

\author{
G. Bryan Young, Warren T. Blume, George A. Wells, \\ Wilson C. Mertens and Suzanne Eder
}

\begin{abstract}
A review of patients with epilepsy showed that $5.9 \%$ had seizures exclusively in sleep (ES) and $4.7 \%$ had seizures predominantly but not exclusively in sleep (PS). These groups were compared with a group (W) with seizures mainly in wakefulness. The following significant differences were obtained: 1) generalized convulsions predominated in the ES while partial seizures were more common among PS and W patients, 2) seizures occurred less frequently in the ES group, and 3) more W patients had EEGs with generalized epileptiform activity and positive family histories for epilepsy.

We suggest the lower frequency of seizures in the ES group and the declining prevalence of sleep epilepsy are due to: 1) the high proportion of generalized as opposed to partial seizures in sleep and 2) more effective control of generalized seizures compared to partial seizures by modern anti-epileptic drug management.
\end{abstract}

RÉSUMÉ: Aspects différentiels de l'épilepsie du sommeil Une révision de nos patients épileptiques a montré que $5.9 \%$ font des crises uniquement lors du sommeil (ES) et qu'un autre $4.7 \%$ font des crises de façon prédominante, mais non exclusive, lors du sommeil (PS). Ces patients furent comparés à un groupe (W) chez qui les crises ne sont qu'à l'éveil. Nous observons les différences significatives suivantes: (1) les convulsions généralisées prédominent ches les ES alors que les crises partielles sont plus fréquentes chez les sujets PS et W; (2) les convulsions sont moins fréquentes dans le groupe ES; (3) plus de patients W avaient des EEG avec une activité épileptiforme généralisée et une histoire familiale d'épilepsie positive.

Nous suggérons que la fréquence plus basse des crises dans le groupe ES et la prévalence à la baisse d'épilepsie du sommeil sont dues: 1) à la proportion plus élevée de crises généralisées que partielles lors du sommeil et 2) au meilleur contrôle des crises généralisées par les traitements anti-épileptiques modernes.

Can. J. Neurol. Sci. 1985; 12:317-320

\begin{abstract}
"Sleep epilepsy" and "nocturnal epilepsy" are terms applied to seizure disorders in which the attacks occur only or predominantly during sleep. Most authors have considered sleep epilepsy as a single entity, contrasting it to seizures occurring on awakening or occurring randomly in the wake-sleep cycle.

We examined two groups of patients with sleep epilepsy those with seizures occurring only during sleep and a group with seizures predominantly but not exclusively during sleep - to determine how they differed from each other and from a group with seizures mainly in wakefulness.
\end{abstract}

\section{METHODS}

We searched our files of patients who were followed in epilepsy clinics at the University Hospitals in London, Ontario and Saskatoon, Saskatchewan for those with seizures exclusively in sleep (ES group) and for those with attacks predominantly but not exclusively in sleep (PS group). To obtain a comparable group of patients with attacks mainly in wakefulness (W group) we selected 71 patients in alphabetical order, from the remainder. Because patients with seizures only in sleep infrequently develop seizures in wakefulness after six years (Gibberd and Bateson, 1974) we established a subgroup of ES patients with seizure disorders of greater than six years (ES>6 subgroup).

Seizures were grouped according to the International Classification of Epileptic Seizures (1981) when possible. Because of the difficulty in determining whether generalized convulsive seizures occurring in sleep were primary or secondarily generalized, they were classified as "generalized convulsions"

From the Department of Clinical Neurological Sciences (Doctors Young. Blume and Mertens); the Department of Statistics and Actuarial Sciences (Dr. Wells), the University of Western Ontario and the Department of Clinical Neurological Sciences, the University of Saskatchewan (Dr. Eder)

Received June 17, 1985. Accepted August 13, 1985

Reprint requests to: Dr. G. Bryan Young. Department of Clinical Neurological Sciences, Victoria Hospital, London. Ontario, Canada N6A 4G5 
unless clinical or electroencephalographic (EEG) features indicated a focal onset. The latter were classified then as partial seizures (evolving into secondarily generalized seizures).

Seizure frequency was arbitrarily defined as "low" if seizures averaged less than once every two months and "high" for more frequent attacks.

Family history was considered positive if a first or second degree relative ever had an epileptic seizure.

Awake EEG's were divided into four categories: 1) bilaterally synchronous epileptiform discharges (BSED) in homologous regions; 2 ) focal: single or multiple spike or sharp wave foci and secondary bilateral synchrony; 3) nonspecific (nonepileptiform abnormality in a focal, multifocal or generalized distribution and 4) normal. If both epileptiform and nonepileptiform abnormalities were seen on the same patient's recording(s), classification was made on the basis of the epileptiform activity. Sleep was considered to "activate" epileptiform discharges if such appeared only then or if their quantity was unequivocally augmented.

We excluded the following patients: those with fewer than three seizures, those with any seizures due to drug or alcohol withdrawal, those with any pseudoseizures (Liske and Forster, 1964), children under three years of age at the time of the last visit and those with febrile seizures. Chi-square statistical tests for comparison of proportions and linear trends across the groups were used on various study variables.

\section{RESULTS}

One thousand, three hundred and eighty-one patients passed our exclusionary criteria. Of these, $81(5.9 \%)$ were in the ES group, 34 were in the ES subgroup and $66(4.7 \%)$ qualified for the PS group. Comparing ES, ES $>6$ subgroup, PS and W groups, no significant differences were found in the ratio of males to females, mean age of seizure onset or mean duration of the seizure disorder (Table 1).

Of patients in the ES group and ES $>6$ subgroup a higher proportion had generalized convulsions than did patients in PS and $\mathrm{W}$ groups (chi-square $=26.66, p<.005$ comparing $\mathrm{ES}, \mathrm{W}$ and PS groups; chi-square $=13.95, \mathrm{p}<.05$ comparing $\mathrm{ES}<6$, PS and W groups). (See Table 1).

Fifty-seven of 61 patients in the ES group and 31 of 34 patients in the ES $>6$ subgroup averaged seizures less than once every two months (See Table 2). These values differed significantly from PS and W groups, in which about half the patients had seizures twice or more than twice per two months (chisquare $=22.16, \mathrm{p}<.005$ comparing ES, PS and $\mathrm{W}$ groups; chi-square $=13.95, p=.001$ comparing ES $>6, P S$ and $W$ groups). Table 2 also shows that within the $W$ group women fared better than men, with proportionately more in the "low" frequency category $(\mathrm{p}<.01)$.

Although etiology of the seizures could be determined in a higher proportion of W patients ( 28 of 71 ) than PS ( 22 of 66 ) and

Table 1: Clinical data for different groups of patients with sleep epilepsy

\begin{tabular}{|c|c|c|c|c|c|c|}
\hline Group & $\begin{array}{c}\text { Number of } \\
\text { Patients } \\
\text { (Male:Female) }\end{array}$ & $\begin{array}{l}\text { Mean Age of } \\
\text { Seizure Onset } \\
\text { (S.D.) }\end{array}$ & $\begin{array}{c}\text { Mean Duration since } \\
\text { onset of Seizures } \\
\text { (S.D.) }\end{array}$ & $\begin{array}{l}\text { Generalized } \\
\text { Convulsions } \\
\text { (Male:Female) }\end{array}$ & $\begin{array}{c}\text { Seizure Type } \\
\text { Simple } \\
\text { Partial } \\
\text { (Male:Female) }\end{array}$ & $\begin{array}{c}\text { Complex } \\
\text { Partial } \\
\text { (Male:Female) }\end{array}$ \\
\hline $\begin{array}{l}\text { Exclusively } \\
\text { Sleep }\end{array}$ & $\begin{array}{c}18 \\
(49: 32)\end{array}$ & $\begin{array}{l}20 \text { years } \\
\text { (17) }\end{array}$ & $\begin{array}{l}6 \text { years } \\
(6)\end{array}$ & $\begin{array}{c}59 \\
(37: 22)\end{array}$ & $\begin{array}{c}15 \\
(10: 5)\end{array}$ & $\begin{array}{c}7 \\
(2: 5)\end{array}$ \\
\hline $\begin{array}{l}\text { Exclusively } \\
\text { Sleep } \\
\text { (>6 years duration) }\end{array}$ & $\begin{array}{c}34 \\
(17: 17)\end{array}$ & $\begin{array}{l}17 \text { years } \\
\text { (14) }\end{array}$ & $\begin{array}{l}12 \text { years } \\
(12)\end{array}$ & $\begin{array}{c}25 \\
(14: 11)\end{array}$ & $\begin{array}{c}5 \\
(2: 3)\end{array}$ & $\begin{array}{c}4 \\
(1: 3)\end{array}$ \\
\hline $\begin{array}{l}\text { Predominantly } \\
\text { Sleep }\end{array}$ & $\begin{array}{c}66 \\
(42: 24)\end{array}$ & $\begin{array}{l}16 \text { years } \\
(15)\end{array}$ & $\begin{array}{l}11 \text { years } \\
\text { (9) }\end{array}$ & $\begin{array}{c}27 \\
(15: 12)\end{array}$ & $\begin{array}{c}19 \\
(12: 7)\end{array}$ & $\begin{array}{c}20 \\
(15: 10)\end{array}$ \\
\hline Wakefulness & $\begin{array}{c}71 \\
(35: 36)\end{array}$ & $\begin{array}{l}19 \text { years } \\
(16)\end{array}$ & $\begin{array}{l}9 \text { years } \\
(9)\end{array}$ & $\begin{array}{c}25 \\
(7: 18)\end{array}$ & $\begin{array}{c}17 \\
(11: 6)\end{array}$ & $\begin{array}{c}25 \\
(15: 10)\end{array}$ \\
\hline
\end{tabular}

\begin{tabular}{|c|c|c|c|}
\hline Group & Total Patients & $\begin{array}{c}\text { Low } \\
<1 \text { per } 2 \text { months }\end{array}$ & $\begin{array}{c}\text { High } \\
>1 \text { per } 2 \text { months }\end{array}$ \\
\hline & $\overline{\text { (male:female) }}$ & (male:female) & (male:female) \\
\hline $\begin{array}{l}\text { Exclusively } \\
\text { Sleep }\end{array}$ & $\begin{array}{c}61 \\
(40: 21)\end{array}$ & $\begin{array}{c}57 \\
(39: 18)\end{array}$ & $\begin{array}{c}4 \\
(1: 3)\end{array}$ \\
\hline $\begin{array}{l}\text { Exclusively } \\
\text { Sleep } 6 \text { years } \\
\text { duration }\end{array}$ & $\begin{array}{c}34 \\
(17: 17)\end{array}$ & $\begin{array}{c}31 \\
(17: 14)\end{array}$ & $\begin{array}{c}3 \\
(0: 3)\end{array}$ \\
\hline $\begin{array}{l}\text { Predominantly } \\
\text { Sleep }\end{array}$ & $\begin{array}{c}56 \\
(36: 20)\end{array}$ & $\begin{array}{c}28 \\
(17: 11)\end{array}$ & $\begin{array}{c}28 \\
(19: 9)\end{array}$ \\
\hline Wakefulness & $\begin{array}{c}64 \\
(32: 32)\end{array}$ & $\begin{array}{c}34 \\
(11: 23)\end{array}$ & $\begin{array}{c}30 \\
(21: 9)\end{array}$ \\
\hline
\end{tabular}

Numbers listed are those for whom seizure control was known.
ES (21 of 81), the differences were small. Trauma was the most common cause, but did not differentiate the groups. Other causes were too infrequent to classify.

With the $W$ group 27 of 71 had a positive family history for seizure(s) compared with 6 of the 81 ES patients and 9 of the 66 PS patients $(\mathrm{p}<.001)$.

A higher proportion of PS patients ( 21 of 66 ) had abnormal neurological examinations compared with ES patients (18 of 81 ), ES>6 patients ( 7 of 27 ) and $W$ patients ( 21 of 71 ). Differences did not quite reach statistical significance, however. Similar types of abnormalities were found in the three groups including mental subnormality, hemiparesis and athetosis. (Abnormalities possibly related to drug therapy such as nystagmus and peripheral neuropathy were not included). 
BSED were found in the EEGs of 19 of $68 \mathrm{~W}$ patients, 7 of 64 ES patients, 3 of 27 ES $>6$ patients and 5 of 56 PS patients (chi-square $=10.8, \mathrm{p}<.01$ comparing ES, PS and $\mathrm{W}$ groups; chi-square $=9.0, p<.05$ comparing $E S>6$, PS and $W$ groups.) No other significant differences were noted in EEGs, including differences in activation by sleep. Only sleep stages I and II were recorded, however.

\section{Discussion}

Several authors (Gowers, 1901; Gibberd and Bateson, 1974; Janz, 1974; D'Allesandro, 1983) reported that 11 to $30 \%$ of patients whose seizures initially occur only in sleep may ultimately develop seizures during wakefulness. Since this usually occurs within six years (Gibberd and Bateson, 1974), we established a subgroup within the ES group with seizures only in sleep for at least six years.

However, the same tendencies and differences shown in the ES group were also found in the ES $>6$ subgroup when compared with PS and W groups. We found that ES and PS groups are distinct and differ from each other in seizure type and ease of control.

In patients whose seizures occur only in sleep generalized convulsions are the principal seizure type. Although generalized convulsions in sleep would seem more likely to attract attention than focal seizures, the latter usually awaken patients (Janz, 1953; Kajtor, 1961). It is, therefore, unlikely that the high proportion of generalized convulsions in the ES group is due to unwitnessed focal seizures. Janz (1962) and Gibberd and Bateson (1974) also found in patients with sleep epilepsy that generalized convulsions predominated over focal, absence, atypical absence and myoclonic seizures. It is difficult to determine, however, how often apparently generalized convulsions in sleep have a focal onset. Using clinical and EEG data this remained a probiem in our study and in other studies. A prospective study using EEG and video monitoring may be required.

The ES group had a higher proportion of patients with seizures occurring, on average, less than once every two months. This is likely due to the higher proportion with generalized convulsions in the ES group than in the PS and W groups. Rodin (1968) and Turnbull (1984) found that generalized convulsions are more easily prevented with anti-epileptic drugs than are partial seizures. This may also account for the higher proportion of females compared with males in the "low" frequency category in the W group: more females than males had generalized convulsions within that group.

Figure 1 gives a graphic display of the previous and present studies of sleep epilepsy. (Only the studies of Kajtor (1962), Gibberd and Bateson (1974), D'Allesandro (1983) and our study identify the ES group while others combine ES and PS groups.) The relative occurrence of sleep epilepsy in these series varies from $7.5 \%$ to $45 \%$. Those series which considered only patients with generalized convulsions as their population, would be expected to have a higher proportion with sleep epilepsy than studies which considered all seizure types. Also it should be noted that studies in more recent years have similar and lower percentages of sleep epilepsy than earlier series. This likely reflects the greater success of the modern anti-epileptic drug management in treating generalized convulsions as opposed to partial seizures, the latter being more likely to be diurnal in occurrence.

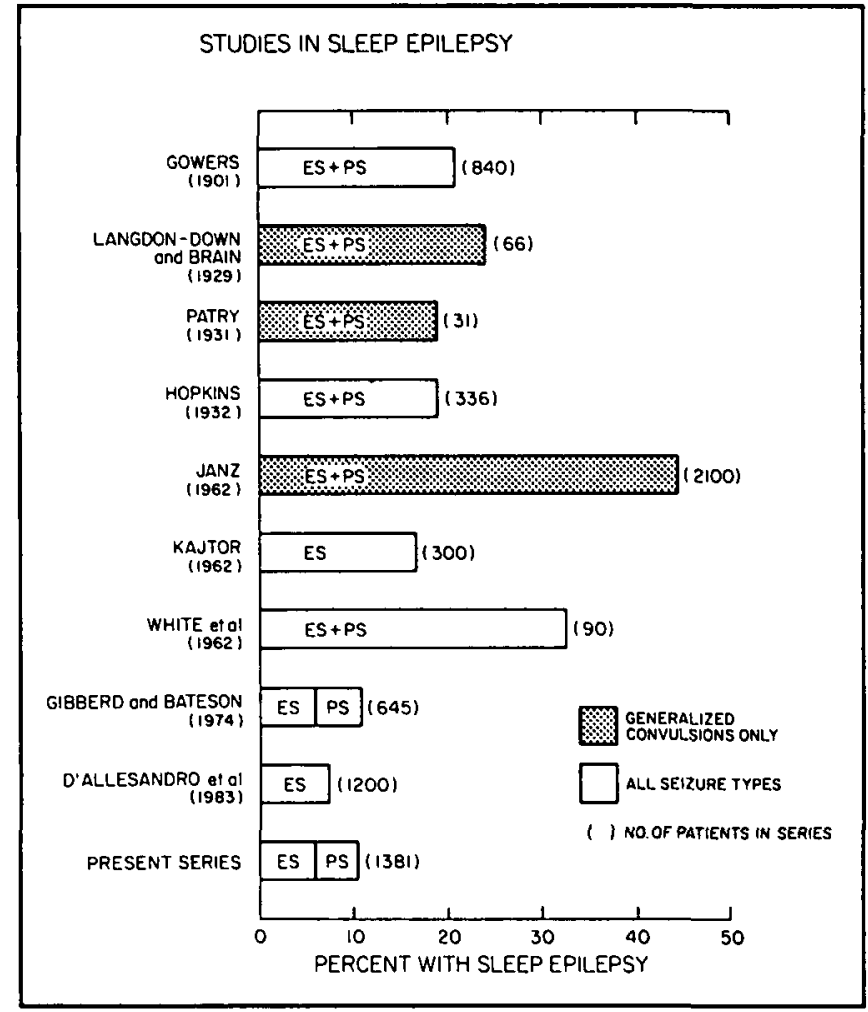

Figure I - A chronological graph of studies in sleep epilepsy. See text.

Our $\mathrm{W}$ group had a higher percentage with a positive family history of seizures than did PS and ES groups, a finding in agreement with Janz (1962). The W group also had a higher proportion with generalized EEG epileptiform activity compared to those with sleep epilepsy, an observation made by others (Christian, 1960; Kajtor, 1962; Janz, 1962; Gibberd and Bateson, 1974). These findings correlate with the observation of Metrakos and Metrakos (1969) that patients with primary generalized seizures commonly have a positive family history for epilepsy and for generalized EEG epileptiform activity.

Daly (1973) pointed out that our knowledge of the biochemicalanatomical symtems underlying the basic rest-activity cycle, the sleep process itself and epilepsy are not sufficiently well-developed to explain the pathophysiology of sleep epilepsy. This is still true, and further effort is needed to determine how the seizure type and origin, the circadian sleep-wake cycle, the stages of sleep, "excitability cycles" (Kellaway, 1980). age and other factors interact. In addressing these issues it is important to recognize the two subgroups of sleep epilepsy.

\section{REFERENCFS}

Christian W (1960) Bioelectrishe charakteristick lagesperiodisch gebundener verlaufsformen epileptischer erkrankungen. Disch Z Nervenheilk 181: 413-444.

Commission on Classification and Terminology of the ILAE (1981) Proposal for revised clinical and electroencephalographic classification of epileptic seizures. Epilepsia 22: 489-501.

D’Allesandro R, Sintini M, Pazzaglia P, Lugaresi E (1983) Pure sleep epilepsies: prognostic features. In: Nistico G, DiPerri R, Meinardi $H$ (eds), Epilepsy: Update on Research and Therapy. New York. Allan R Liss, pp 235-239.

Daly DD (1973) Circadian cycles and seizures. In Brazier MAB (ed). Epilepsy: Its Phenomena in Man, New York, Academic Press, pp 215-233. 
Gibberd FB, Bateson MC (1974) Sleep epilepsy: its pattern and prognosis. Br Med J 2: 403-405.

Gowers WR (1901) Epilepsy and Other Chronic Convulsive Disorders: Their Causes, Symptoms and Treatment, London: Churchill, pp 162-164.

Hopkins $H$ (1933) The time of appearance of epileptic seizures in relation to age, duration and type of the syndrome. 77: 153-162.

Janz D (1953) "Nacht"-, oder "Schlaf" epilepsien als ausdruckeiner verlaufsform epileptischer Erkraukungen. Nervenarzt 24: 361-380.

Janz D (1962) The grand mal epilepsies and the sleep-waking cycle. Epilepsia 3: 69-109.

Janz D (1974) Epilepsy and the sleep-waking cycle. In: Vol 15 The Epilepsies. Magnus O, Lorentz de Maas AM (eds), The Handbook of Clinical Neurology, Amsterdam, New York, North Holland Publishing Co, pp 457-490.

Kajtor F (1961) Some anatomo-functional factors which may predispose to epileptic seizures occurring during sleep. Electroenceph clin Neurophysiol 13: 400-410.

Kajtor F (1962) The influence of sleep and the waking state on the epileptic activity of different cerebral structures. Epilepsia 3:274-280.
Kellaway P, Frost JD, Crawley JW (1980) Time modulation of spike and wave discharge in generalized epilepsy. Ann Neurol 8: 491-500.

Langdon-Down M, Brain WR (1929) Time of day in relation to convulsions in epilepsy. Lancet 1: 1029-1032.

Liske E, Forster (1964) Pseudoseizures: a problem in diagnosis and management of epileptic patients. Neurology (Minneap) 14: 41-49.

Metrakos JD, Metrakos K (1969) Genetic studies in clinical epilepsy. In: Jasper HH, Ward AA, Pope A (eds) Basic Mechanisms of the Epilepsies, Boston, Little Brown and Co. pp 700-708.

Patry FL (1931) The relation of time of day, sleep and other factors in the incidence of epileptic seizures. Am J Psychiatry 87: 789-813.

Rodin EA (1968) The Prognosis of Patients with Epilepsy. Springfield, CC Thomas, pp 179-262.

Turnbull DM, Rawlins MD, Weightman D, Chadwick DW (1984) "Therapeutic" serum concentration of phenytoin: the influence of seizure types. J Neurol Neurosurg Psychiatry 47: 231-234.

White P, Dyken M, Grant P, Jackson L (1962) Electroencephalographic abnormalities during sleep as related to temporal distribution of seizures. Epilepsia 3: 67-174. 